$$
\begin{array}{l|l|l}
\text { Jurnal Eksplorasi Akuntansi } & \text { e-ISSN: 2656-3649 (Online) } \\
\text { Vol 3, No 2, Mei 2021, Hal 450-469 } & \text { http://jea.ppj.unp.ac.id/index.php/jea }
\end{array}
$$

\title{
Pengaruh Pendapatan Asli Daerah (PAD), Kekayaan Daerah dan Sisa Lebih Pembiayaan Anggaran (SILPA) Terhadap Belanja Modal dengan Pertumbuhan Ekonomi sebagai Variabel Moderasi pada Pemerintah Provinsi se-Indonesia Periode 2015-2019
}

\author{
Danil Sanjaya ${ }^{1^{*}}$, Herlina Helmy ${ }^{2}$ \\ ${ }^{1}$ Jurusan Akuntansi Fakultas Ekonomi Universitas Negeri Padang \\ ${ }^{2}$ Jurusan Akuntansi Fakultas Ekonomi Universitas Negeri Padang \\ *Korespondensi: danilsanjaya525@gmail.com
}

\begin{abstract}
This study aims to determine the effect of Regional Original Income (PAD), regional Asset and Excess Budget Financing (SILPA) on Capital Expediture with Economic Growth as a Moderating Variable in Provincial Governments throughout Indonesia 20152019. The data use in this study is the report on the realization of APBD for the 2015-2019 fiscal year which is available on the DJPK website. The population and sample in this study ara all provincial governments in Indonesia consisted of 34 provinces from 2015-2019 with a total of 170 data. Hypothesis testing in this study uses the Moderated Regression Analysis (MRA) test. The result show that PAD has no significant effect on capital expenditure, Regional Wealth and SILPA have a significant effect and simultaneously independent variables have a significant effect on the dependent variable, Economic Growth strengthens the influence of PAD and SILPA on capital expenditure and Economic Growth weakens Regional wealth on Capital Expenditure.
\end{abstract}

Keywords: Original Regional Income, Regional Wealth, Remaning Budget Financing, Capital Expenditures, Economic Growth.

How to cite (APA $6^{\text {th }}$ style)

Sanjaya, D \& Hekmy. (2021). Pengaruh Pendapatan Asli Daerah (PAD), Kekayaan Daerah dan Sisa Lebih Pembiyaan Anggaran (SILPA) Terhadap Belanja Modal dengan Pertumbuhan Ekonomi sebagai Variabel Moderasi pada Pemerintah Provinsi seIndonesia Periode 2015-2019. Jurnal Eksplorasi Akuntansi. 3(2). 450-469.

\section{PENDAHULUAN}

Berawal dari peristiwa krisis ekonomi yang melanda Indonesia pada tahun 1997 dan pada tahun 1998 Indonesia puncak dari masalah tersebut yang mana pada tahun tersebut disebut sebagai tahun krisis moneter, hal tersebut membuat perekonomian Indonesia terpuruk sehingga pemerintah mengeluarkan kebijakan Otonomi Daerah (Erdi \& Rachmawati, 2015). Menurut Andre (2014) pemerintah melakukan reformasi bertujuan untuk memperbaiki perekonomian Indonesia baik dibidang pemerintahan maupun dibidang pengelolaan. UndangUndang Nomor 32 tahun 2004 menyatakan bahwa pemerintah pusat memberikan kewenangan kepada pemerintah daerah untuk mengelola daerahnya sendiri, kewenangan yang diberikan kepada pemerintah daerah tersebut beriringan dengan tujuan dari kebijakan 
otonomi daerah.

Yang mana tujuan dari kebijakan otonomi daerah adalah pemerintah daerah diminta untuk dapat menciptakan kemandirian daerahnya masing-masing dalam hal meningkatkan kesejahteraan dan pelayanan publik serta pemerintah daerah diminta untuk dapat membangun daerah dengan menggali potensi dan sumber-sumber kekayaan daerah agar dapat mengurangi ketergantungan kepada pemerintah pusat (Ikhwan, 2011). Menurut Widya (2018) kebijakan dan strategi yang perlu ditentukan oleh pemerintah daerah untuk mencapai pembangunan yang diinginkan salah satunya adalah peningkatan investasi suatu daerah.

Menurut Prasetya (2015) sumber kekayaan yang dimiliki oleh daerah tidak sebanding dengan kebutuhan fiskal setiap daerah membuat pemerintah daerah dihadapkan dengan masalah kebutuhan fiskal yang sangat tinggi, hal ini menyebabkan kesenjangan fiskal antara pemerintah pusat dengan pemerintah daerah. Dana perimbangan seperti dana alokasi umum (DAU) adalah bantuan yang diberikan pemerintah pusat ke pemerintah daerah untuk mengatasi kesenjangan fiskal antara pemerintah pusat dengan pemerintah daerah (DAU) (Erdi \& Rachmawati, 2015). Pemerintah pusat berharap kepada pemerintah daerah agar pembangunan dan pelayanan setiap daerah mengalami peningkatan dengan bantuan yang telah diberikan dari pemerintah pusat kepada pemerintah daerah, maka yang harus dilakukan pemerintah daerah agar harapan tersebut tercipta adalah dengan mengalokasikan belanja pada investasi modal (Harianto \&Adi, 2007).

Elni (2019) menyatakan Pendapatan Asli Daerah (PAD) yang tinggi mencerminkan tingkat partisipasi publik terhadap pembangunan mengalami peningkatan, serta menggambarkan pada pembangunan dan kualitas pelayanan publik mengalami peningkatan hal ini dikarenakan tingginya investasi modal. Mengoptimalkan potensi pendapatan daerah adalah salah satu upaya yang dilakukan pemerintah daerah untuk meningkatkan kemandirian daerah dengan meningkatkan pengalokasian belanja modal ke sektor-sektor yang dianggap produktif (Nugroho dikutip dari Sugiarthi \& Supadmi, 2014). Pemerintah daerah harus mengalokasikan penerimaan secara adil dan merata antara belanja modal dengan belanja operasi agar pembangunan meningkat.

Belanja modal merupakan pengeluaran yang dilakukan untuk menambah aset atau kekayaan dan juga akan menambah belanja yang bersifat rutin. Pemerintah daerah berbelanja dengan tujuan untuk melakukan pembangunan dan perbaikan sektor pendidikan, kesehatan, dan transportasi sehingga masyarakat juga menikmati manfaat dari pembangunan daerah (Frelistiyani, 2010). Dalam melakukan pembangunan ekonomi suatu daerah yang sangat berperan penting adalah Belanja modal dikarenakan Belanja modal memiliki masa manfaat jangka panjang untuk memberikan pelayanan kepada publik (Nuarisa,2013).

Menurut Putro (2011) ketimpangan fiskal yang terjadi antara satu daerah dengan daerah lainnya merupakan akibat dari kemampuan keuangan setiap daerah yang tidak sama dalam mendanai kegiatan mereka masing-masing, untuk mengatasi fenomena tersebut dana yang bersumber dari APBN dialokasikan pemerintah untuk pendanaan daerah masing-masing supaya desentralisasi suatu daerah terlaksana. Rendy (2018) menyatakan bahwa belanja modal lebih banyak dialokasikan pada belanja rumah tangga kurang produktif yang mengakibatkan pertumbuhan ekonomi yang tidak sejalan dengan peningkatan belanja modal. Tahun 2015 sampai 2019 dilihat dari data yang diperoleh dari Laporan Realisasi Anggaran Tahun 2015-2019 belanja daerah yang dialokasikan pada belanja modal provinsi se-Indonesia masih rendah atau terdapat beberapa tahun yang alokasi belanja modal menurun, pada tahun 2015 belanja daerah yang dialokasikan ke belanja modal sebesar 18,1\% atau senilai Rp 45.154.453.564.132 dari belanja daerah yang berjumlah Rp 248.817.586.941.033, pada tahun 2016 alokasi belanja modal turun menjadi 16,9\% atau senilai Rp 44.714.4227.251.308 dari belanja daerah yang berjumlah $\mathrm{Rp}$ 263.957.378.259.363, sedangkan pada tahun 2017 alokasi belanja modal naik menjadi 17\% senilai Rp 47.355.091.112.056 dari belanja daerah 
sebesar 279.281.456.756.088, pada tahun 2018 alokasi belanja modal kembali turun menjadi 15,8\% senilai Rp 51.519.460.514.732 dari belanja daerah sebesar Rp 326.284.740.606.916, dan pada tahun 2019 alokasi belanja modal mengalami penurunan kembali menjadi 14,2\% senilai 50.519.279.220.806 dari belanja daerah sebesar Rp 355.916.442.806.810.

Belanja modal yang mengalami fluktusi dari tahun 2015 ke 2019 disebabkan karena anggaran belanja mayaoritas untuk belanja gaji pegawai hal ini sesuai dengan pernyataan Menteri Keuangan RI Ibu Sri Mulyani, yang menyatakan bahwa pemerintah daerah mayoritas masih mengutamakan anggaran belanja untuk dialokasikan ke belanja gaji pegawai dibanding belanja infrastruktur. Terdapat 19\% rata-rata belanja modal yang dilakukan pemda diseluruh Indonesia. Berdasarkan data Kementerian Keuangan per juli 2018 anggaran belanja daerah sebesar Rp. 1.153 triliun, namun presentase sebesar 36\% atau Rp. 410,6 triliun di serap untuk belanja pegawai. $23 \%$ untuk belanja barang dan jasa selebihnya $19 \%$ adalah total belanja modal pemda. Melihat data tersebut menunjukkan bahwa pemda belum efekif dalam mengalokasikan anggaran secara tepat (Kompas.com,2018). Fenomena lain ditunjukan pada Pemerintah provinsi Riau dimana realisasi belanja yang bersumber dari APBN mencapai Rp. 15.04 triliun mengalami penurunan sebesar 3,90 dari realisasi tahun sebelumnya.

Kepala kanwil Ditjen Perbendaharaan provinsi Riau menjelaskan bahwa penurunan realisasi belanja diakibatkan karena perubahan pola belanja yang dialakukan dalam rangka penanganan wabah Covid-19. Hal ini mengakibatkan belanja modal yang terealisasi hanya mncapai $22 \%$, hal ini menunjukkan belanja modal belum bisa bisa dialokasikan secara optimal dimana tujuan belanja modal sebelumnya diaharapkan bisa meningkatkan pertumbuhan ekonomi namun belum terealisasi secara optimal oleh pemda provinsi Riau (Kabar Sumatera.com,2020). Realisasi belanja modal yang rendah juga ditunjukkan oleh Pemerintah Provinsi Jawa Barat pada tahun 2019. Dimana hal ini dilihat dari sisa anggaran lebih pembiayaann anggaran (SILPA) yang masih tinggi yaitu sebesar Rp.3.26 triliun hal ini menjelaskan sekitar 9,13\% bersisa dari yang dianggarkan. Tingginya SILPA mengakibatkan banyaknya program pemerintah yang tidak dilakukan secara optimal sehingga peran dan fungsi utama pemerintah untuk memberikan pelayanan publik terganggu. Selain itu menurut Iwan Fraksi PKS menyoroti terdapat realisasi belanja modal hanya Rp.2.53 triliun dari Rp.3.26 triliun yang dianggarkan, rendahnya belanja modal menghambat pembangunan infrastruktur publik yang seharusnya dapat dimaksimalkan untuk kesejahteraan masyarakat (wartaekonomi,2019).

Peningkatan pertumbuhan ekonomi merupakan tujuan yang diharapkan oleh suatu daerah, untuk pencapaian tujuan tersebut diharapkan kepada pemerintah daerah untuk menjalankan otonomi daerahnya yang telah diberikan kewenangan dari pemerintah pusat untuk mengelola keuangan pemerintah daerah masing-masing. Pertumbuhan ekonomi dalam penelitian ini dijadikan sebagai variabel pemoderasi untuk memperkuat maupun memperlemah hubungan antara PAD, kekayaan daerah, dan SILPA terhadap belanja modal. Beberapa penelitian yang pernah dilakukan yaitu penelitian yang dilakukan Sugiarti (2014) memperoleh hasil bahwa PAD berpengaruh positif terhadap belanja modal.

Penelitian yang membahas keterkaitan antara DAU PAD dengan belanja modal telah dilakukan oleh Riviando et.al (2019) pada kabupaten dan kota di propinsi Sumatera Barat. Riset ini menemukan DAU dan DAK berpengaruh positif terhadap belanja modal. Berikutnya penelitian Paujiah (2012) menunjukkan hasil bahwa PAD tidak berpengaruh signifikan terhadap belanja modal. Penelitian yang dilakukan oleh Windra (2013) menyimpulkan bahwa DAU dengan arah negatif, DAK dan DBH berpengaruh signifikan terhadap belanja modal. Selanjutnya penelitian Supadmi (2014) menyimpulkan bahwa PAD, DAU dan SiLPA berpengaruh positif dan signifikan pada belanja modal, variabel moderasi mampu memoderasi PAD dan DAU namun tidak mampu memoderasi Variabel SILPA pada belanja modal. Penelitian Dwirandra (2014) menyimpulkan bahwa PAD berpengaruh positif 
terhadap belanja modal, pertumbuhan ekonomi berpengaruh signifikan dan mampu memoderasi pengaruh PAD pada belanja modal tetapi dengan arah yang berlawanan.

\section{REVIEW LITERATUR DAN HIPOTESIS}

Teori Keagenan (Agency Theory)

Teori keagenan adalah teori yang menyatakan bahwa hubungan keagenan merupakan suatu persetujuan (kontrak) di antara dua pihak (prinsipal dengan agen), dimana prinsipal memberikan wewenang kepada agen untuk mengambil keputusan atas nama prinsipal (Yonita dikutip Erdhi, 2015). Yonita (2011) dikutip Erdhi (2015) menjelaskan bahwa teori keagenan merupakan cabang dari gane theory yang mempelajari suatu model kontraktual yang mana disaat kepentingan agen bertentangan dengan kepentingan prinsipal akan mendorong agen untuk bertindak bagi prinsipal.

Pihak agent bertanggung jawab dalam memaksimakan keuntungan bagi principal, dan agent juga berkepentingan untuk meningkatkan kesejahteraan sendiri, kenyataanya wewenang yang diberikan principal kepada agent sering bermasalah karena tujuan principal berbenturan dengan tujuan agent. Menurut Jensen ada dua macam masalah agensi yaitu: Moral Hazard, dan Adverse Selection.

\section{Anggaran Pendapatan dan Belanja Daerah (APBD)}

Menurut (Undang-Undang No 32, 2004) tentang "perimbangan keuangan antara pemerintah pusat dan pemerintah daerah" Anggaran Pendapatan Belanja Daerah (APBD) adalah rencana keuangan tahunan pemerintah daerah yang dibahas dan disetujui oleh pemerintah daerah serta disetujui juga oleh Dewan Perwakilan Rakyat Daerah (DPRD). Anggaran Pendapatan Belanja Daerah (APBD) mencakup anggaran pendapatan daerah, anggaran belanja daerah dan pembiayaan.

\section{Belanja Modal}

Menurut (frelistiyani, 2004) Belanja modal adalah pengeluaran pemerintah daerah yang membuat aset atau kekayaan daerah bertambah dan juga akan menambah belanja yang bersifat rutin seperti biaya pemeliharaan yang ada dalam kelompok belanja administrasi umum yang masa manfaatnya melebihi satu tahun anggaran. Menurut (Permendagri Nomor 13, 2006) belanja modal adalah pembiayaan yang mana digunakan untuk pengeluaran seperti pembelian/ pengadaan dan atau pembangunan aset tetap berwujud yang mempunyai nilai manfaat lebih dari dua belas bulan yang akan digunakan dalam kegiatan pemerintahan, seperti dalam bentuk tanah, peralatan, mesin, gedung dan bangunan, jalan, irigasi dan jaringan, serta aset tetap lainya.

\section{Pendapatan Asli Daearah (PAD)}

Pendapatan Asli daerah diperoleh dari pajak daerah, retribusi daerah, hasil pengelolaan kekayaan daerah yang dipisahkan, dan pos lain-lain PAD yang sah. Menurut undang-undang Nomor 33 tahun 2004 tentang "Perimbangan keuangan antara pusat dan daerah" Pendapatan Asli Daerah (PAD) adalah pendapatan daerah yang diperoleh oleh pemerintah daerah masingmasing yang mana dipungut berdasarkan peraturan daerah sesuai dengan peraturan perundang-undangan.

\section{Kekayaan Daerah}

Kekayaan daerah adalah harta atau sumber daya yang dimiliki oleh pemerintah daerah yang digunakan untuk memberikan pelayanan kepada masyarakat. Kekayaan yang besar dimiliki oleh pemerintah daerah menggambarkan bahwa pelayanan publik yang lebih baik, kekayaan dapat dilihat dari total aset yang dapat menggambarkan besarnya sumber daya yang dimiliki 
oleh suatu daerah (Misra, 2019). Menurut PSAP aset merupakan sumber daya ekonomi yang dimiliki dan dikuasai oleh pemerintah atas akibat dari kejadian masa lalu dan diharapkan pemerintah dan masyarakat dapat memperoleh manfaat ekonomi dimasa depan. Total aset yang dimiliki pemerintah daerah diharapkan dapat memberikan kemudahan operasional dan memberikan pelayanan yang baik kepada masyarakat.

\section{Sisa Lebih Pembiayaan Anggaran (SILPA)}

Menurut (PP 71, 2010) lampiran I.02 PSAP 02 penyajian laporan keuangan menjelaskan bahwa SILPA adalah sisa lebih antara realisasi pendapatan-LRA dan belanja, serta penerimaan dan pengeluaran pembiayaan dalam APBN/APBD selama satu tahun periode pelaporan. Sisa lebih pembiayaan anggaran tahun sebelumnya adalah penerimaan pembiayaan daerah yang digunakan untuk menutupi defisit anggaran di saat realisasi pendapatan lebih kecil daripada realisasi belanja (Yana, 2018). Besar kecilnya SILPA dan ada tidaknya SILPA tergantung pada tingkat belanja yang dilakukan pemerintah daerah serta kinerja pendapatan daerah. Jika pendapatan lebih besar dari belanja maka terjadi surplus maka kemungkinan akan diperoleh SILPA yang lebih tinggi. Dan sebaliknya jika belanja lebih besar dari pendapatan maka terjadi defisit maka kemungkinan akan diperoleh Sisa Kurang Pembiayaan Anggaran (SIKPA).

\section{Pertumbuhan Ekonomi}

Pertumbuhan ekonomi adalah proses dimana terjadi kenaikan produk nasional bruto riil atau pendapatan nasional riil. Perekonomian bisa dikatakan tumbuh atau berkembang yang mana bila terjadi pertumbuhan output riil. Kuznets menjelaskan bahwa pertumbuhan ekonomi adalah kondisi dimana suatu negara memiliki kemampuan untuk melakukan peningkatan dalam menyediakan berbagai jenis barang-barang ekonomi dengan jumlah yang banyak kepada pendukungnya. Pertumbuhan ekonomi menjadi hal yang penting dalam suatu negara karena dapat melihat apakah negara tersebut telah berhasil memajukan berbagai aspek kehidupan atau tidak. Istilah pertumbuhan ekonomi sering digunakan untuk menyatakan perkembangan ekonomi, kesejahteraan ekonomi, kemajuan ekonomi dalam jangka panjang suatu negara (Jaeni, 2016).

\section{Pengaruh PAD terhadap Belanja Modal}

Penelitian Jaeni (2016) menemukan bahwa terdapat hubungan yang sangat kuat antara PAD dengan belanja modal, hasil penelitian yang serupa oleh Dwirandra dan jaya (2014) yang menyatakan PAD berpengaruh terhadap belanja modal. Maka ini dapat diartikan bahwa besarnya PAD maka pengeluaran atas belanja modal akan semakin tinggi.

Pendapatan Asli Daerah yang biasanya menjadi sumber utama dari penerimaan pemerintah. Berdasarkan PP No. 58 Tahun 2005 tentang pengelolaan keuangan daerah menyatakan bahwa APBD disusun sesuai dengan penyelenggaraan pemerintah dan kemampuan daerah, maka dari itu dapat diartikan bahwa jika pemerintah daerah ingin mengalokasikan atau menggunakan belanja modalnya, pemerintah daerah harus memperhatikan kebutuhan daerah dengan memperhatikan atau mempertimbangkan PAD yang diterima.

Maka dapat disimpulkan bahwa besar kecilnya belanja modal pemerintah daerah tergantung pada besar kecilnya PAD suatu daerah, sehingga disaat pemerintah daerah ingin meningkatkan pelayanan publik dan meningkatkan kesejahteraan masyarakat dengan upaya meningkatkan belanja modal maka dari itu pemerintah daerah berusaha keras untuk meningkatkan pendapatan asli daerah. Berdasarkan uraian diatas dapat dirumuskan hipotesis sebagai berikut:

H1: Pendapatan Asli Daerah berpengaruh positif terhadap belanja modal 


\section{Pengaruh Kekayaan Daerah terhadap Belanja Modal}

Kekayaan adalah sumber daya yang berfungsi untuk memberikan pelayanan yang lebih baik kepada masyarakat yang dimili oleh pemerintah. Pemerintah yang memiliki kekayaan lebih besar dapat memberikan pelayanan yang lebih baik kepada masyarakat. Kekayaan dapat dilihat dari total aset yang dapat menggambarkan besarnya sumber daya yang dimiliki oleh pemerintah (Usman dkk,2019).

Menurut PSAP aset merupakan sumber daya ekonomi yang dimiliki dan dikuasai oleh pemerintah akibat kejadian masa lalu dan diharapkan pemerintah dan masyarakat dapat memperoleh manfaat ekonomi di masa yang akan datang. Pemerintah dapat memberikan pelayanan yang baik kepada masyarakat didukung dengan aset yang baik pula. Untuk meningkatkan pelayanan pemerintah harus bisa mengalokasikan belanja modalnya untuk menambah fasilitas atau aset untuk pelayanan kepada masyarakat, semakin baik belanja modal yang dimiliki oleh pemerintah maka pelayanan untuk masyarakat semakin baik dengan fasilitas yang memadai. Berdasarkan uraian di atas dapat dirumuskan hipotesis sebagai berikut:

H2: Kekayaan daerah berpengaruh positif terhadap belanja modal

\section{Pengaruh SILPA terhadap Belanja Modal}

Sumber pendanaan lainnya yang dialokasikan untuk belanja modal penyediaan berbagai fasilitas publik selain PAD adalah penerimaan daerah yang bersumber dari Sisa Lebih Pembiayaan Anggaran (SILPA) tahun anggaran sebelumnya. Menurut Permendagri No. 13 Tahun 2006 SILPA merupakan sisa lebih dana yang diperoleh dari selisih antara penerimaan dan pengeluaran anggaran daerah selama satu periode.

Penelitian yang dilakukan Sugiarti dan Supadmi (2014) menyatakan bahwa SILPA berpengaruh positif terhadap belanja modal. Sejalan dengan Ardhini (2011) yang menyatakan bahwa SILPA berpengaruh positif terhadap belanja modal. Maka dari hasil tersebut menunjukkan bahwa SILPA adalah salah satu sumber pendapatan atau pendanaan belanja modal, karna sisa lebih pembiayaan anggaran tersebut akan dialokasikan ke dalam belanja modal untuk meningkatkan pertumbuhan ekonomi suatu daerah.

Besar kecilnya SILPA dan ada tidaknya SILPA tergantung pada tingkat belanja yang dilakukan pemerintah daerah serta kinerja pendapatan daerah. Jika pendapatan lebih besar dari belanja maka terjadi surplus maka kemungkinan akan diperoleh SILPA yang lebih tinggi. Dan sebaliknya jika belanja lebih besar dari pendapatan maka terjadi defisit maka kemungkinan akan diperoleh Sisa Kurang Pembiayaan Anggaran (SIKPA). Berdasarkan uraian diatas dapat dirumuskan hipotesis sebagai berikut:

H3: Sisa Lebih Pembiayaan Anggaran (SILPA) berpengaruh positif terhadap belanja modal

\section{Pertumbuhan Ekonomi Memoderasi Pengaruh PAD Terhadap Belanja Modal}

Menurut Erdi \& Rachmawati (2015) pembangunan yang dilakukan pemerintah daerah berperan penting dalam pembangunan tersebut, yang mana pemerintah daerah harus memperhatikan faktor-faktor sumber daya alam, tenaga kerja, investasi modal, kewirausahaan, transportasi, pengeluaran pemerintah dan dukungan pembangunan. pertumbuhan ekonomi sering dijadikan istilah untuk menyatakan bahwa perekonomian suatu daerah berkembang, sejahtera, dan maju dalam jangka waktu panjang (Jaeni, 2016).

Erdi \& Rachmawati (2015) menjelaskan bahwa kewenangan pemerintah daerah dalam pelaksanaan kebijakannya sebagai daerah otonomi sangat mempengaruhi kemampuan daerah dalam menghasilkan pendapatan daerah, semakin tinggi pendapatan asli daerah yang diperoleh, maka pelayanan publik akan meningkat dan memajukan perekonomian daerah. Salah satu cara untuk meningkatkan pelayan publik dengan melakukan belanja untuk kepentingan investasi yang derealisasi melalui belanja modal (Ardhini 2011 dikutip 
Erdi ,2015). Menurut Dwirandra (2014) peningkatan pertumbuhan ekonomi suatu daerah juga mampu menarik minat investor untuk berinvestasi di daerah sehingga PAD semakin meningkat, PAD yang tinggi akan digunakan oleh pemerintah daerah untuk memberikan pelayan publik sehingga akan meningkatkan belanja modal. Pertumbuhan ekonomi dalam penelitian ini digunakan sebagai variabel moderasi. Tingkat pertumbuhan ekonomi diduga dapat memperkuat pengaruh pendapatan asli daerah terhadap belanja modal.

Erdhi (2015) menyatakan bahwa semakin tinggi tingkat pertumbuhan ekonomi berpengaruh pada peningkatan pendapatan perkapita sehingga berdampak pada konsumsi suatu penduduk meningkat. Penelitian yang dilakukan oleh Supadmi (2014) memperoleh hasil bahwa pendapatan asli daerah berpengaruh positif dan pertumbuhan ekonomi dapat memoderasi pengaruh PAD terhadap belanja modal. Berdasarkan paparan di atas hipotesis sebagai berikut:

H4: Pertumbuhan ekonomi memoderasi pendapatan asli daerah berpengaruh positif terhadap belanja modal

\section{Pertumbuhan Ekonomi Memoderasi Pengaruh Kekayaan Daerah Terhadap Belanja Modal}

Menurut Misra (2019) pelayanan publik yang baik diberikan oleh pemerintah merupakan dukungan dari kekayaan yang lebih besar dimiliki oleh pemerintah daerah, yang mana kekayaan yang dimiliki oleh daerah dapat dilihat dari total aset yang dapat menggambarkan besarnya sumber daya yang dimiliki oleh suatu daerah. Tingkat pertumbuhan ekonomi yang baik berdampak pada peningkatan pelayanan publik yang meningkat, dalam peningkatan tersebut pemerintah mengalokasikan kekayaan daerah dengan baik. Pertumbuhan ekonomi dalam penelitian ini digunakan sebagai variabel pemoderasi. Meningkatnya pertumbuhan ekonomi suatu daerah akan mempengaruhi kekayaan suatu daerah dan berdampak pada peningkatan belanja modal suatu daerah. Berdasarkan penjelasan diatas dapat ditarik hipotesis penelitian:

H5: Pertumbuhan ekonomi memoderasi kekayaan daerah berpengaruh positif terhadap belanja modal

\section{Pertumbuhan Ekonomi Memoderasi Pengaruh SILPA Terhadap Belanja Modal}

PP No 71 Tahun 2010 tentang Standar Akuntansi Pemerintah menyatakan bahwa SILPA merupakan selisih antara realisasi pendapatan-LRA dan belanja, serta penerimaan dan pengeluaran pembiayaan dalam APBN/APBD selama satu periode pelaporan. Besar kecilnya SILPA dan ada tidaknya SILPA tergantung pada tingkat belanja yang dilakukan pemerintah daerah serta kinerja pendapatan daerah. Menurut Permendagri No 13 Tahun 2006 menyatakan SILPA merupakan sisa dana yan diperoleh dari aktualisasi penerimaan serta pengeluaran anggaran daerah selama satu periode. Dalam penelitian ini pertumbuhan ekonomi sebagai variabel pemoderasi. Pertumbuhan ekonomi diduga memperkuat pengaruh hubungan SILPA terhadap Belanja Modal. Penelitian yang dilakukan Sugiarti dan Supadmi (2014) menyatakan bahwa SILPA berpengaruh positif terhadap belanja modal. Berdasarkan uraian diatas maka ditarik hipotesis sebagai berikut :

H6: Pertumbuhan ekonomi memoderasi SILPA berpengaruh positif terhadap belanja modal

\section{METODE PENELITIAN}

\section{Jenis Penelitian}

Penelitian ini menggunakan jenis penelitian kuantitatif dan termasuk kedalam penelitian kausatif. Penelitian kausatif yaitu penelitian yang menganalisis pengaruh antara suatu variabel terhadap variabel lainnya (Sugiyono, 2012). Jenis data yang dipakai dalam penelitian ini adalah data sekunder (secondary data), yaitu diperoleh peneliti secara tidak 
langsung atau melalui media perantara (diperoleh, dikumpulkan, dan diolah oleh pihak lain). Sumber data dalam penelitian ini diperoleh dari situs Dirjen Perimbangan Keuangan Pemerintah Daerah (DJPK). Data yang digunakan mengenai jumlah realisasi belanja modal, Pendapatan Asli Daerah (PAD), total kekayaan daerah, Selisih Lebih Pembiayaan Anggaran (SILPA), serta pertumbuhan ekonomi.

Data yang digunakan dalam penelitian ini dikumpulkan dengan menggunakan metode dokumentasi, yaitu mempelajari dokumen-dokumen ataupun data-data yang digunakan mengenai jumlah Realisasi Belanja Modal, Pendapatan Asli Daerah (PAD), Total Kekayaan daerah, Selisih Lebih Pembiayaan Anggaran (SILPA), serta pertumbuhan ekonomi pada pemerintahan provinsi se-Indonesia tahun 2015-2019.

\section{Pengukuran Variabel \\ Belanja Modal}

$$
\begin{aligned}
& \text { Belanja Modal = Belanja Tanah + Belanja Peralatan dan Mesin + Belanja Gedung dan } \\
& \text { Belanja Jalan, Irigrasi, dan Jaringan + Belanja Aset Tetap Lainnya }
\end{aligned}
$$

Sumber : PP No 71 tahun 2010

Menurut (Permendagri Nomor 13, 2006) belanja modal adalah pembiayaan yang mana digunakan untuk pengeluaran seperti pembelian/pengadaan dan atau pembangunan aset tetap berwujud yang mempunyai nilai manfaat lebih dari dua belas bulan yang akan digunakan dalam kegiatan pemerintahan, seperti dalam bentuk tanah, peralatan, mesin, gedung dan bangunan, jalan, irigasi dan jaringan, serta aset tetap lainya.

\section{Pendapatan Asli Daerah (PAD)}

Pendapatan Asli daerah diperoleh dari pajak daerah, retribusi daerah, hasil pengelolaan kekayaan daerah yang dipisahkan, dan pos lain-lain PAD yang sah. Menurut undang-undang Nomor 33 tahun 2004 tentang "Perimbangan keuangan antara pusat dan daerah" Pendapatan Asli Daerah (PAD) adalah pendapatan daerah yang diperoleh oleh pemerintah daerah masing-masing yang mana dipungut berdasarkan peraturan daerah sesuai dengan peraturan perundang-undangan.

PAD = Pajak + Retribusi + Pengelolaan Kekayaan Daerah Terpisah + PAD Lain Yang Sah

Sumber : UU No. 33 tahun 2004

\section{Kekayaan Daerah}

Kekayaan Daerah adalah sumber daya yang dimiliki oleh pemerintah daerah yang mana sumber daya tersebut akan digunakan untuk memberikan pelayanan kepada masyarakat.Menurut PSAP aset merupakan sumber daya ekonomi yang diperoleh dari akibat kejadian masa lalu yang dimiliki dan dikuasai oleh pemerintah dan pemerintah daerah serta masyarakat mengharapkan manfaat ekonomi dimasa depan. Besar kekayaan daerah diukur dengan melihat total aset.

Kekayaan Daerah $=$ Total Asset

Sumber : Armaja et al.,2015 


\section{SILPA (Sisa Lebih Pembiayaan Anggaran)}

Menurut PP 71 tahun 2010 lampiran I.02 PSAP 02 penyajian laporan keuangan menjelaskan bahwa SILPA adalah sisa lebih antara realisasi pendapatan-LRA dan belanja, serta penerimaan dan pengeluaran pembiayaan dalam APBN/APBD selama satu tahun periode pelaporan. Jumlah SILPA diukur dengan melihat nilai SILPA yang disajikan dalam laporan realisasi APBD.

\section{Pertumbuhan Ekonomi}

Menurut Hasan (2012) Pertumbuhan Ekonomi adalah alat ukur yang digunakan untuk mengukur suatu kegiatan pembangunan. Kuznets menjelaskan bahwa pertumbuhan ekonomi adalah kondisi dimana suatu negara memiliki kemampuan untuk melakukan peningkatan dalam menyediakan berbagai jenis barang-barang ekonomi dengan jumlah yang banyak kepada pendukungnya.

$$
G=\frac{P D R B_{1}-P D R B_{0}}{P D R B_{0}} \times 100 \%
$$

Sumber : Kusumawardani, Dewi(2009)

Keterangan :

$\mathrm{G} \quad=$ Tingkat pertumbuhan ekonomi

PDRB1 $=$ PDRB tahun uji

PDRB0 $=$ PDRB sebelum tahun uji

\section{HASIL DAN PEMBAHASAN}

Uji Asumsi Klasik

1. Uji Normalitas

Tabel 1 Hasil Uji Normalitas

One-Sample Kolmogorov-Smirnov Test

\begin{tabular}{|c|c|c|}
\hline & & $\begin{array}{c}\text { Unstandardized } \\
\text { Residual }\end{array}$ \\
\hline $\begin{array}{l}\text { N } \\
\text { Normal Parameters }{ }^{\mathrm{a}, \mathrm{b}} \\
\text { Most Extreme Differences } \\
\text { Test Statistic } \\
\text { Asymp. Sig. (2-tailed) }\end{array}$ & $\begin{array}{l}\text { Mean } \\
\text { Std. Deviation } \\
\text { Absolute } \\
\text { Positive } \\
\text { Negative }\end{array}$ & $\begin{array}{r}170 \\
, 0000000 \\
, 13391693 \\
, 059 \\
, 027 \\
-, 059 \\
, 059 \\
, 200^{\mathrm{c}, \mathrm{d}} \\
\end{array}$ \\
\hline $\begin{array}{l}\text { a. Test distribution is Norm } \\
\text { b. Calculated from data. } \\
\text { c. Lilliefors Significance C }\end{array}$ & on. & \\
\hline
\end{tabular}

Sumber: Data Sekunder yang diolah, 2021

Berdasarkan tabel 1 diatas menjelaskan bahwa hasil uji normalitas menunjukkan bahwa nilai Sig $>0,05$ yaitu $0,200>0,05$. Jadi dapat disimpulkan bahwa nlai residual data penelitian berdistribusi normal. 


\section{Uji Multikolinieritas}

Tabel 2 Hasil Uji Multikolinieritas

Coefficients $^{\mathrm{a}}$

\begin{tabular}{|c|c|c|c|c|c|c|c|c|}
\hline \multirow{2}{*}{\multicolumn{2}{|c|}{ Model }} & \multicolumn{2}{|c|}{$\begin{array}{c}\text { Unstandardized } \\
\text { Coefficients }\end{array}$} & \multirow{2}{*}{$\begin{array}{c}\text { Standardized } \\
\text { Coefficients }\end{array}$} & \multirow[b]{2}{*}{$\mathrm{t}$} & \multirow[b]{2}{*}{ Sig. } & \multicolumn{2}{|c|}{$\begin{array}{c}\text { Collinearity } \\
\text { Statistics }\end{array}$} \\
\hline & & $\mathrm{B}$ & Std. Error & & & & Tolerance & VIF \\
\hline \multirow[t]{5}{*}{1} & (Constant) & 3,525 & ,303 & & 11,628 &, 000 & & \\
\hline & $\log \_x 1_{1}$ &,- 032 & ,039 &,- 052 &,- 829 & ,408 & ,269 & 3,716 \\
\hline & $\log x 2$ & ,606 & ,046 & 845 & 13,098 & ,000 &, 251 & 3,983 \\
\hline & $\log \times 3$ & ,084 & ,024 & 155 & 3,571 & ,000 & ,553 & 1,807 \\
\hline & $\mathrm{PM}$ & 001 & ,003 &, 014 &, 429 & ,669 & ,990 & 1,010 \\
\hline
\end{tabular}

a. Dependent Variable: Log_Y

Sumber: Data Sekunder yang diolah, 2021

Berdasarkan tabel 2 diatas menjelaskan bahwa nilai tolerance pada masing-masing variabel nilai tolerance $>0,10$ dan pada nilai VIF terlihat bahwa nilai VIF $<10$, ini menjelaskan bahwa tidak terjadi gejala multikolineritas.

\section{Uji Heterokadastisitas}

Tabel 3 Hasil Uji Heterokedastisitas

Coefficients $^{\mathrm{a}}$

\begin{tabular}{|c|c|c|c|c|c|c|}
\hline \multirow{2}{*}{\multicolumn{2}{|c|}{ Model }} & \multicolumn{2}{|c|}{ Unstandardized Coefficients } & \multirow{2}{*}{$\begin{array}{c}\text { Standardized } \\
\text { Coefficients } \\
\text { Beta }\end{array}$} & \multirow[b]{2}{*}{$\mathrm{t}$} & \multirow[b]{2}{*}{ Sig. } \\
\hline & & B & Std. Error & & & \\
\hline \multirow[t]{5}{*}{1} & (Constant) & ,387 & 183 & & 2,112 & ,036 \\
\hline & $\log \times 1$ &,- 022 & 023 &,- 138 &,- 932 & ,353 \\
\hline & $\log _{-} \mathrm{x} 2$ &,- 003 & ,028 &,- 015 &,- 095 & ,924 \\
\hline & $\log \times 3$ & 002 &, 014 &, 013 &, 127 & ,899 \\
\hline & PM & 001 & ,002 &, 025 & ,326 & ,744 \\
\hline
\end{tabular}

a. Dependent Variable: abs_RES

Sumber: Data Sekunder yang diolah, 2021

Berdasarkan tabel 3 diatas menjelaskan bahwa uji masing-masing variabel menunjukkan bahwa nilai sig $>0,05$, hal ini menjelaskan bahwa kesimpulan dari uji heterokedastisitas adalah tidak terjadi heterokedastisitas.

\section{Uji autokorelasi}

Tabel 4 Hasil Uji Autokorelasi

Model Summaryb

\begin{tabular}{|c|c|c|c|c|c|}
\hline Model & $\mathrm{R}$ & R Square & $\begin{array}{c}\text { Adjusted R } \\
\text { Square }\end{array}$ & $\begin{array}{c}\text { Std. Error of the } \\
\text { Estimate }\end{array}$ & Durbin-Watson \\
\hline 1 &, $910^{\mathrm{a}}$ &, 828 &, 823 &, 13553 & 1,844 \\
\hline
\end{tabular}

a. Predictors: (Constant), PM, Log_x1, Log_x3, Log_x2

b. Dependent Variable: Log_Y

Sumber: Data Sekunder yang diolah, 2021

Hasil uji autokorelasi pada tabel 4 menunjukkan bahwa nilai Durbin Watson sebesar 1,844. Angka tersebut menunjukan bahwa nilai D-W berada diantara -2 sampai $+2(-2<\mathrm{D}-\mathrm{W}<+2)$. Nilai D-W berada diantara $-2>1,844<+2$. Berdasarkan hasil pengujian tersebut dapat 
disimpulkan tidak terjadi autokorelasi.

\section{Regresi Linear Berganda}

Tabel 5 Regresi Linear Berganda

Coefficients $^{\mathrm{a}}$

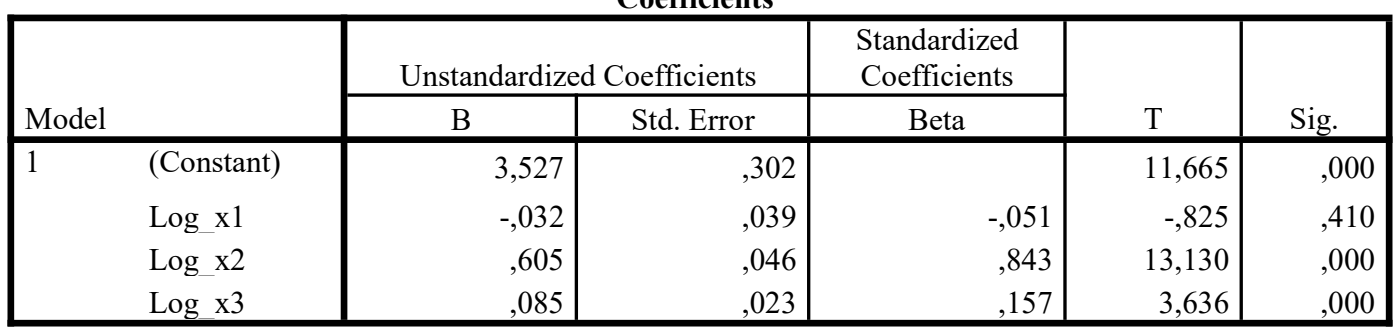

a. Dependent Variable: Log_Y

Sumber : Data Sekunder yang diolah, 2021

Berdasarkan tabel 5 diatas dapat di peroleh persamaan regresi linear berganda sebagai berikut :

$$
\mathrm{Y}=3,527-0,032(\mathrm{PAD})+\mathbf{0 , 6 0 5}(\mathrm{KD})+\mathbf{0 , 0 8 5}(\mathrm{SILPA})+\mathrm{e}
$$

\section{Uji Koefisien Determinasi (R2)}

Tabel 6 Hasil Uji Koefisien Determinasi (R2)

Model Summary

\begin{tabular}{|l|r|r|r|c|}
\hline Model & \multicolumn{1}{|c|}{ R } & R Square & $\begin{array}{c}\text { Adjusted R } \\
\text { Square }\end{array}$ & $\begin{array}{c}\text { Std. Error of the } \\
\text { Estimate }\end{array}$ \\
\hline 1 &, $910^{\mathrm{a}}$ &, 827 &, 824 &, 13520 \\
\hline
\end{tabular}

a. Predictors: (Constant), $\log _{-} \mathrm{x} 3, \log _{-} \mathrm{x} 1, \log _{-} \mathrm{x} 2$

Sumber : Data Sekunder yang diolah, 2021

Berdasarkan tabel 6 diatas menggambarkan bahwa besar nilai Adjusted $\mathrm{R}$ square adalah 0,824. Hal ini menjelaskan bahwa kontribusi variabel independent Pendapatan Asli Daerah (PAD), kekayaan daerah, dan Sisa Lebih Pembiayaan Anggaran (SILPA) adalah sebesar $82,4 \%$ untuk sisanya sebesar $17,6 \%$ ditentukan oleh faktor lain diluar penelitian.

\section{Uji F (Simultan)}

Tabel 7 Hasil Uji F (Simultan) ANOVA ${ }^{\mathrm{a}}$

\begin{tabular}{|ll|r|r|r|r|r|}
\hline Model & & Sum of Squares & Df & Mean Square & F & Sig. \\
\hline 1 & Regression & 14,546 & 3 & 4,849 & 265,270 &, $000^{\mathrm{b}}$ \\
& Residual & 3,034 & 166 &, 018 & & \\
& Total & 17,580 & 169 & & & \\
\hline
\end{tabular}

a. Dependent Variable: Log_Y

b. Predictors: (Constant), Log_x3, Log_x1, Log_x2

Sumber : Data Sekunder yang diolah, 2021

Berdasarkan tabel 7 diatas menggambarkan bahwa hasil uji $\mathrm{F}$ mempunyai signifikansi sebesar 0,000 dimana sig 0,000<0,05, hal ini menjelaskan bahwa secara bersama-sama variabel independent (PAD, kekayaan daerah, dan SILPA) berpengaruh signifikan terhadap variabel dependent (Belanja Modal). Ini berarti bahwa persamaan regresi yang didapat bisa diandalkan. 


\section{Uji t (Hipotesis)}

Tabel 8 Hasil Uji t

Coefficients $^{\mathrm{a}}$

\begin{tabular}{|ll|r|r|r|r|r|}
\hline & & \multicolumn{2}{|c|}{$\begin{array}{c}\text { Standardized } \\
\text { Coefficients }\end{array}$} & \multicolumn{1}{c|}{} \\
\cline { 3 - 4 } Model & & \multicolumn{2}{|c|}{ B } & Std. Error & Beta & \multicolumn{1}{c|}{ Sig. } \\
\hline 1 & (Constant) & 3,527 &, 302 & & 11,665 &, 000 \\
& Log_x1 &,- 032 &, 039 &,- 051 &,- 825 &, 410 \\
& Log_x2 &, 605 &, 046 &, 843 & 13,130 &, 000 \\
& Log x3 &, 085 &, 023 &, 157 & 3,636 &, 000 \\
\hline
\end{tabular}

a. Dependent Variable: $\log$ Y

Sumber : Data Sekunder yang diolah, 2021

Dari tabel diatas dapat dilihat nilai PAD sebesar 0,41. Nilai probabilitas $0,41>0,05$. Artinya PAD tidak berpengaruh signifikan terhadap belanja modal pada provinsi di Indonesia. Dapat disimpulkan bahwa hipotesis pertama (H1) ditolak. hal ini menjelaskan bahwa kabupaten dan kota dengan PAD yang besar tidak menggambarkan bahwa belanja modal yang besar. Hal ini desebabkan karena PAD yang diterima lebih diperioritaskan pada belanja lain, seperti belanja rutin. Rendy (2018) menyatakan bahwa kabupaten dan kota yang memiliki PAD yang besar cenderung tidak memiliki belanja modal yang besar, hal ini dikarekan bahwa PAD yang diterima lebih banyak dilokasikan untuk membiayai belanjapegawai,belanja rutin/operasional,dll.

Nilai probabilitas kekayaan daerah sebesar 0,000 . Nilai probabilitas $0.000<0,05$. Artinya kekayaan daerah berpengaruh signifikan terhadap belanja modal. Dapat disimpulkan bahwa hipotesis kedua (H2) diterima, karena kekayaan daerah yang tinggi akan meningkatkan belanja modal, begitu sebaliknya jika kekayaan daerah rendah maka belanja modal akan rendah. Hasil penelitian yang menunjukkan bahwa SILPA berpengaruh signifikan tehadap belanja modal juga diketahui karena SILPA di setiap provinsi di Indonesia digunakan untuk belanja modal yang tediri dari belanja tanah, peralatan dan mesin, gedung dan bangunan, jalan, irigasi dan belanja asset tetap lainnya dan nilai SILPA sebesar 0,000.

Nilai Probabilitas $0,000<0,05$. Artinya SILPA berpengaruh signifikan terhadap Belanja Modal. Dapat disimpulkan bahwa hipotesis ketiga (H3) diterima, Maka dari hasil tersebut menunjukkan bahwa SILPA adalah salah satu sumber pendapatan atau pendanaan belanja modal, karna sisa lebih pembiayaan anggaran tersebut akan dialokasikan ke dalam belanja modal untuk meningkatkan pertumbuhan ekonomi suatu daerah. Dari hasil penelitian ini menunjukkan bahwa SILPA yang besar akan meningkatkan Belanja modal dan begitu sebaliknya, 


\section{Moderated Regression Analysis (MRA)}

Tabel 9 Hasil Uji Moderated Regression Analysis (MRA)

Coefficients $^{\mathrm{a}}$

\begin{tabular}{|c|c|c|c|c|c|c|}
\hline \multirow[b]{2}{*}{ Mod } & & \multicolumn{2}{|c|}{ Unstandardized Coefficients } & $\begin{array}{l}\text { Standardized } \\
\text { Coefficients }\end{array}$ & \multirow[b]{2}{*}{$\mathrm{T}$} & \multirow[b]{2}{*}{ Sig. } \\
\hline & & $\mathrm{B}$ & Std. Error & Beta & & \\
\hline \multirow[t]{8}{*}{1} & (Constant) & 4,244 & 9,550 & & ,444 & 658 \\
\hline & $\log _{-} X 1$ &,- 072 & ,759 &,- 127 &,- 094 & ,925 \\
\hline & $\log X 2$ & ,557 & ,739 & ,785 & ,753 & , 454 \\
\hline & $\log X 3$ & ,097 & ,037 & 207 & 2,621 & ,011 \\
\hline & PM &,- 207 & ,546 &,- 824 &,- 379 & ,706 \\
\hline & $\mathrm{PAD} * \mathrm{PM}$ & ,002 & ,058 & ,066 & ,029 & 977 \\
\hline & $\log _{-} x 2 . z$ & ,020 & ,040 &, 045 & ,495 & ,622 \\
\hline & SILPA*PM & ,016 & ,045 & ,784 & ,365 & ,717 \\
\hline
\end{tabular}

a. Dependent Variable: $\log \_\mathrm{y}$

Sumber : Data Sekunder yang diolah, 2021

Dari tabel 9 diatas dapat membuat persamaan moderated Regresssion Analysis (MRA) sebagai berikut :

$$
Y=4,244-0,072 X_{1}+0,557 X_{2}+0,097 X_{3}+0,002 X_{1} \cdot Z+0,020 X_{2} \cdot Z+0,016 X_{3} \cdot Z+9,550
$$

\section{Pertumbuhan Ekonomi Memoderasi pengaruh PAD terhadap Belanja Modal}

Tabel 10 Hasil Uji Regresi sebelum ada variabel moderasi

\begin{tabular}{|l|r|r|r|c|}
\hline Model & $\mathrm{R}$ & $\mathrm{R}$ Square & $\begin{array}{c}\text { Adjusted R } \\
\text { Square }\end{array}$ & $\begin{array}{c}\text { Std. Error of the } \\
\text { Estimate }\end{array}$ \\
\hline 1 &, $763^{\mathrm{a}}$ &, 583 &, 580 &, 20900 \\
\hline
\end{tabular}

a. Predictors: (Constant), $\log _{-} \mathrm{X} 1$

Sumber : Data Sekunder yang diolah, 2021

Tabel 11 Hasil Uji Regresi sesudah ada variabel moderasi

Model Summary

\begin{tabular}{|c|c|c|c|c|}
\hline Model & $\mathrm{R}$ & R Square & $\begin{array}{c}\text { Adjusted R } \\
\text { Square }\end{array}$ & $\begin{array}{l}\text { Std. Error of the } \\
\text { Estimate }\end{array}$ \\
\hline 1 &, $902^{\mathrm{a}}$ &, 813 & ,809 & ,14079 \\
\hline
\end{tabular}

a. Predictors: (Constant), PAD*PM, PM, $\log _{-} \mathrm{X} 1$

Sumber : Data Sekunder yang diolah, 2021

Dari tabel 10 diatas terlihat nilai $\mathrm{R}$ Square sebesar 0,583, hal ini mejelaskan bahwa partisiapasi variabel PAD terhadap variabel Belanja Modal sebesar 58,3\%, setelah adanya variabel moderasi atau dapat kita lihat pada tabel 11 nilai $\mathrm{R}$ Square meningkat menjadi 0,813 atau 81,3\%. Maka dapat disimpulkan bahwa hipotesis ke empat diterima, maka dapat dikatakan bahwa keberadaan variabel perumbuhan ekonomi (sebagai variabel moderasi) dapat memperkuat pengaruh PAD terhadap belanja modal.

\section{Pertumbuhan Ekonomi Memoderasi pengaruh Kekayaan daerah terhadap Belanja Modal.}

Dalam penelitian ini hipotesis kelima adalah pertumbuhan ekonomi memoderasi pengaruh kekayaan daerah terhadap belanja modal. Berikut tabel hasil Uji MRA : 
Tabel 12 Hasil Uji Regresi sebelum ada variabel moderasi Model Summary

\begin{tabular}{|l|r|r|r|c|}
\hline Model & $\mathrm{R}$ & $\mathrm{R}$ Square & $\begin{array}{c}\text { Adjusted R } \\
\text { Square }\end{array}$ & $\begin{array}{c}\text { Std. Error of the } \\
\text { Estimate }\end{array}$ \\
\hline 1 &, $902^{\mathrm{a}}$ &, 814 &, 813 &, 13966 \\
\hline
\end{tabular}

a. Predictors: (Constant), $\log _{-} \mathrm{X} 2$

Sumber : Data Sekunder yang diolah, 2021

Tabel 13 Hasil Uji Regresi sesudah ada variabel moderasi Model Summary

\begin{tabular}{|l|r|r|r|c|}
\hline Model & $\mathrm{R}$ & R Square & $\begin{array}{c}\text { Adjusted R } \\
\text { Square }\end{array}$ & $\begin{array}{c}\text { Std. Error of the } \\
\text { Estimate }\end{array}$ \\
\hline 1 &, $878^{\mathrm{a}}$ &, 770 &, 760 &, 13930 \\
\hline
\end{tabular}

a. Predictors: (Constant), $\log$ x $2 . z, \log \_X 2, P M$

Sumber: Data Sekunder yang diolah, 2021

Dari tabel 12 diatas terlihat nilai $\mathrm{R}$ Square sebesar 0,814, hal ini mejelaskan bahwa partisiapasi variabel kekayaan daerah terhadap variabel belanja modal sebesar $81,4 \%$, setelah adanya variabel moderasi atau dapat kita lihat pada tabel 13 nilai $\mathrm{R}$ Square menurun menjadi 0,770 atau $77 \%$. Maka dapat disimpulkan bahwa hipotesis kelima ditolak, maka dapat dikatakan bahwa keberadaan variabel pertumbuhan ekonomi (sebagai variabel moderasi) memperlemah pengaruh kekayaan daerah terhadap belanja modal. Berdasarkan hasil penelitian ini yang menyatakan bahwa pertumbuhan ekonomi memoderasi (memperkuat) pengaruh PAD tehadap belanja modal.

Artinya, semakin tinggi petumbuhan ekonomi maka pengaruh PAD terhadap belanja modal akan meningkat. Untuk meningkatkan pertumbuhan ekonomi pemerintah harus meningkatkan pengalokasin belanja daerahnya ke belanja modal dan menggunakan pendapatan asli daerahnya ke belanja modal. pertumbuhan ekonomi yang tinggi akan membuat pengaruh kekayaan daerah terhadap belanja modal menurun. Pada saat petumbuhan ekonomi suatu daerah meningkat ini menggambarkan bahwa fasilitas dan pelayanan disuatu daerah tersebut sudah baik, maka dari itu pemeritah daerah akan mengurangi pengalokasian belanja modalnya dan mengalokasikan ke belanja lainnya seperti belanja pegawai dan belanja barang dan jasa.

\section{Pertumbuhan Ekonomi Memoderasi pengaruh SILPA terhadap Belanja Modal}

Dalam penelitian ini hipotesis keenam adalah Pertumbuhan Ekonomi Memoderasi pengaruh SILPA terhadap Belanja Modal. Berikut tabel hasil Uji MRA :

Tabel 14 Hasil Uji Regresi sebelum ada variabel moderasi Model Summary

\begin{tabular}{|l|r|r|r|c|}
\hline Model & $\mathrm{R}$ & R Square & \multicolumn{1}{c|}{$\begin{array}{c}\text { Adjusted R } \\
\text { Square }\end{array}$} & $\begin{array}{c}\text { Std. Error of the } \\
\text { Estimate }\end{array}$ \\
\hline 1 &, $675^{\mathrm{a}}$ &, 456 &, 452 &, 23866 \\
\hline
\end{tabular}

a. Predictors: (Constant), $\log \mathrm{X} 3$

Sumber : Data Sekunder yang diolah, 2021

Tabel 15 Hasil Uji Regresi sesudah ada variabel moderasi Model Summary

\begin{tabular}{|l|r|r|r|r|}
\hline Model & $\mathrm{R}$ & R Square & \multicolumn{1}{|c|}{$\begin{array}{c}\text { Adjusted R } \\
\text { Square }\end{array}$} & $\begin{array}{c}\text { Std. Error of the } \\
\text { Estimate }\end{array}$ \\
\hline 1 &, $676^{\mathrm{a}}$ &, 457 &, 447 &, 23976 \\
\hline
\end{tabular}

a. Predictors: (Constant), SILPA*PM, log X3, PM

Sumber : Data Sekunder yang diolah, 2021 
Dari tabel 14 diatas terlihat nilai R Square sebesar 0,456, hal ini mejelaskan bahwa partisiapasi variabel SILPA terhadap variabel belanja modal sebesar $45.6 \%$, setelah adanya variabel moderasi atau dapat kita lihat pada tabel 15 nilai R Square meningkat menjadi 0.457 atau 45,7\%. Maka dapat disimpulkan bahwa hipotesis keenam diterima, maka dapat dikatakan bahwa keberadaan variabel pertumbuhan ekonomi (sebagai variabel moderasi) memperkuat pengaruh SILPA terhadap Belanja Modal. Peningkatan petumbuhan ekonomi ini berarti bahwa penerimaan atau pendapatan daerah lebih besar dibandingkan pengeluran daerah, dan ini menjelaskan bahwa jika pendapatan lebih besar dari pengeluaran maka SILPA tahun berjalan meningkat. Ketika suatu daerah mengalami peningkatan pertumbuhan ekonomi, maka pemerintah daerah akan mengurangi pembiyaan anggaran untuk belanja modal dan akan di alokasikan ke belanja lain seperti belanja pegawai, barang dan jasa dan lain-lain.

\section{PEMBAHASAN}

\section{Pengaruh Pendapatan Asli Daerah (PAD) Terhadap Belanja Modal}

Hipotesis pertama dalam penelitian ini adalah Pendapatan Asli Daerah (PAD) berpengaruh positif terhadap belanja modal, disini menjelaskan bahwa pendapatan suatu daerah yang tinggi akan meningkatkan anggaran melanja modal. Menurut Made (2018) salah satu faktor penentu dalam menentukan anggaran belanja modal adalah Pendapatan Asli Daerah (PAD) dimana alokasi belanja modal disesuaikan dengan kebutuhanserta mempertimbangkan PAD yang diterima.

Dalam penelitian ini memperoleh hasil bahwa hipotesis pertama (H1) ditolak. Dengan hasil yang diperoleh peneliti menunjukkan bahwa Pendapatan Asli Daerah (PAD) tidak berpengaruh terhadap belanja modal. Hasil penelitian ini sejalan degan peneltian yang dilakukan oleh Eka Pariani pada tahun 2018 yang mana juga memperoleh hasil bahwa Pendapatan Asli Daerah (PAD) tidak berpengaruh terhadap belanja modal. Hal ini menjelaskan bahwa kabupaten dan kota dengan PAD yang besar tidak menggambarkan bahwa belanja modal yang besar, hal ini desebabkan karena PAD yang diterima lebih diperioritaskan pada belanja lain, seperti belanja rutin.

Hasil penelitian ini sejalan dengan beberapa penelitian yang pernah dilakukan sebelumnya, yaitu penelitian yang dilakukan Erdi Adyatma (2015) memperoleh hasil bahwa PAD tidak berpengaruh terhadap belanja modal. Arbie Gugus Wandira (2013) memperoleh hasil bahwa PAD tidak berpengruh signifikan terhadap belanja modal, dan penelitian yang dilakukan oleh Widya Yana (2018) memperoleh hasil yang sama bahwa PAD tidak memiliki pengaruh terhadap belanja modal. Hal ini menjelaskan bahwa PAD yang tinggi belum menentukan bahwa pengeluaran pemerintah atas belanja modal akan semakin tinggi, karna penerimaan yang diperoleh oleh pemerintah juga digunakan untuk belanja lain-lain.

Hasil penelitian ini berbeda dari beberapa penelitian terdahulu yaitu penelitian Kartika Jaya dan Dwirandra (2014), Jaeni (2016), Wimpi Priambudi (2017), Rudi Hermawan (2017), Desak Made Mya Yudia Sari (2018). Dari beberapa penelitian terdahulu tersebut menyatakan bahwa PAD berpengaruh signifikan terhadap belanja modal. Dari hasil penelitian terdahulu ini menjelaskan bahwa PAD yang semakin tinggi membuat belanja modal mengalami peningkatan, begitu sebaliknya jika PAD menurun maka belanja modal mengalami penurunan.

Hasil dalam penelitian ini menunjukkan bahwa PAD tidak signifikan mempengaruhi belanja modal karena peningkatan pada PAD tidak sebanding dengan peningkatan belanja modal. Berdasarkan hasil analisis peneliti beberapa Provinsi di Indonesia pada tahun 20152019 rata-rata pada lima tahun tersebut menjelaskan bahwa jumlah PAD dialokasikan pada belanja modal tidak sebanding dengan peningkatan PAD, diantaranya adalah Provinsi Sumatera Utara yang mana rata-rata PAD dari lima tahun tersebut bejumlah 5,3 triliun dan 
alokasi ke belanja modal hanya 25,2\% atau sebesar 1,3 triliun, dan Provinsi Jawa Barat ratarata PAD dari lima tahun tersebut berjumlah 18,4 triliun dengan alokasi kebelanja modal hanya $14,3 \%$ atau sebesar 2,6 triliun. Sehingga dapat kita nilai bahwa pada Provinsi Sumatera Utara dan Jawa Barat menjelaskan bahwa alokasi belanja daerah lebih banyak digunakan pada belanja lain-lain seperti belanja pegawai, belanja hibah dibandingkan pada belanja modal. Rendy (2018) menyatakan bahwa kabupaten dan kota yang memiliki PAD yang besar cendrung tidak memiliki belanja modal yang besar, hal ini dikarekan bahwa PAD yang diterima lebih banyak dilokasikan untuk membiayai belanja pegawai, belanja rutin/operasional,dan lain-lain. Berdasarkan hasil analisis penelitian yang dilakukan peneliti, peneliti memperoleh atau mendapatkan data PAD terbaru serta pengujian analisis regresi berganda.

\section{Pengaruh Kekayaan Daerah Terhadap Belanja Modal}

Hipotesis ke dua dalam penelitian ini adalah kekayaan daerah berpengaruh posistif terhadap belanja modal, yang dimana kekayaan dapat dilihat pada total aset yang dapat menggambarkan besarnya sumber daya yang dimiliki oleh pemerintah (Usman dkk,2019). Kekayaan merupakan sumber daya yang dimilki oleh pemerintah daerah yang berfungsi untuk meberikan pelayanan yang lebih baik kepada masyarakat.

Berdasarkan hasil uji atau hasil penelitian yang dilakukan penelitian ini, peneliti memperoleh hasil bahwa kekayaan daerah berpengaruh positif terhadap belanja modal, dimana dengan hasil yang diperoleh maka hipotesis ke dua (H2) diterima. Hasil penelitaan ini menunjukkan bahwa kekayaan daerah berpengaruh signifikan terhadap belanja modal. Belanja modal merupakan pengeluaran pemerintah daerah yang dapat menambah aset atau kekayaan daerah. Dimana semakin tinggi kekayan daerah suatu daerah maka semakin tinggi belanja modal yang dilakukan oleh pemerintah daerah.

Penelitian yang menunjukkan hasil bahwa kekayaan daerah berpengaruh signifikan terhadap belanja modal, karena kekayaan daerah yang tinggi akan meningkatkan belanja modal, begitu sebaliknya jika kekayaan daerah rendah maka belanja modal akan rendah. Hasil penelitian tersebut didukung oleh data yang menunjukkan bahwa benar kekayaan didaerah yang meningkat membuat belanja modal juga meningkat, yaitu pada provinsi Aceh pada tahun 2018 kekayaan daerah berjumlah 24,1 triliun dan pada tahun 2019 meningkat menjadi 28,4 triliun, dan pada peningkatan kekayaan daerah juga diikuti oleh belanja modal pada tahun 2018 belanja modal berjumlah 2,5 triliun dan pada tahun 2019 meningkat menjadi 3,1 triliun. Dan begitu sebaliknya bahwa benar kekayaan daerah yang rendah mengakibatkan belanja modal rendah, Provinsi Lampung kekayaan daerah tahun 2018 berjumlah 88,8 triliun dan pada tahun 2019 menurun menjadi 9,7 triliun dan penurunan kekayaan daerah tersebut juga diikuti penurunan pada belanja modal pada tahun 2018 berjumlah 1,7 triliun dan pada tahun 2019 menurun menjadi 1,0 triliun. Berdasarkan hasil analisis penelitian yang dilakukan peneliti, peneliti memperoleh atau mendapatkan data Kekayaan daerah terbaru serta pengujian analisis regresi berganda.

\section{Pengaruh Sisa Lebih Pembiayaan Anggaran (SILPA) Terhadap Belanja Modal}

Hipotesis ke tiga dalam penelitian ini adalah Sisa Lebih Pembiayaan Anggaran (SILPA) berpengaruh signifikan terhadap belanja, dimana hal tersebut menjelaskan bahwa jumlah SILPA yang besar akan meningkatkan anggaran belanja modal suatu daerah. Liliana et.al dalam Supdami (2014) menyatakan bahwa hubungan antara pendapatan pemerintah daerah dan pengeluaran pemerintah daerah merupakan hubungan yang sangat penting, karena ada tidaknya SILPA tergantung besarnya penerimaan dengan pengeluaran.

Berdasarkan hasil uji yang dilakukan peneliti memperoleh hasil bahwa Sisa Lebih Pembiayaan Anggaran (SILPA) berpengaruh signifikan terhadap belanja modal, maka 
hipotesis ketiga (H3) diterima. Penelitian ini sejalan dengan penelitian yang tedahulu yaitu penelitian yang dilakukan Sugiarti dan Supadmi (2014) menyatakan bahwa SILPA berpengaruh positif terhadap belanja modal. Dan Ardhini (2011) yang menyatakan bahwa SILPA berpengaruh positif terhadap belanja modal.Maka dari hasil tersebut menunjukkan bahwa SILPA adalah salah satu sumber pendapatan atau pendanaan belanja modal, karna sisa lebih pembiayaan anggaran tersebut akan dialokasikan ke dalam belanja modal untuk meningkatkan pertumbuhan ekonomi suatu daerah.

Dari hasil penelitian ini menunjukkan bahwa SILPA yang besar akan meningkatkan Belanja modal dan begitu sebaliknya, dari analisis peneliti data yang mendukung hasil penelitian ini yaitu pada povinsi papua ditahun 2018 SILPA sebesar 1,0 triliun dan pada tahun 2019 meningkat menjadi 2,7 triliun diikuti dengan peningkatan belanja modal pada tahun 2018 bejumlah 1,9 triliun dan meningkat pada tahun 2019 menjadi 2,2 tiliun. Sebalikmya jika SILPA menurun maka belanja modal juga menurun berikut data yang mendukung pada provinsi DKI Jakarta pada tahun 2018 SILPA bejumlah 9,7 triliun dan pada tahun 2019 menurun menjadi 1,2 triliun dan diikuti penurunan belanja modal pada tahun 2018 berjumlah 14,1 triliun menuun pada tahun 2019 menjadi 11,5 triliun.

Hasil penelitian yang menunjukkan bahwa SILPA bepengaruh signifikan tehadap belanja modal juga diketahui karna SILPA di setiap provinsi di Indonesia digunakan untuk belanja modal yang tediri dari belanja tanah, peralatan dan mesin, gedung dan bangunan, jalan, irigasi dan belanja asset tetap lainnya. Berdasarkan hasil analisis penelitian yang dilakukan peneliti, peneliti memperoleh atau mendapatkan data SILPA terbaru serta pengujian analisis regresi berganda.

\section{Pertumbuhan Ekonomi Memoderasi pengaruh PAD Terhadap Belanja Modal}

Hipotesis ke empat dalam penelitian ini adalah pertumbuhan ekonomi memoderasi pengaruh Pendapatan Asli Daerah (PAD) terhadap belanja modal, dimana pertumbuhan ekonomi yang baik akan bepengaruh langsung terhadap besarnya jumlah PAD yang akan membuat PAD meningkat sehingga dapat memaksimalkan belanja modal untuk mengoptimalkan penggunaan anggaran. Pertumbuhan ekonomi menjadi hal yang penting dalam suatu negara karena dapat melihat apakah negara tersebut telah berhasil memajukan berbagai aspek kehidupan atau tidak. Istilah pertumbuhan ekonomi sering digunakan untuk menyatakan perkembangan ekonomi, kesejahteraan ekonomi, kemajuan ekonomi dalam jangka panjang suatu negara (Jaeni, 2016).

Hasil penelitian ini menunjukkan bahwa pertumbuhan ekonomi memperkuat atau memoderasi pengaruh pendapatan asli daerah (PAD) terhadap belanja modal dimana hipotesisi ke empat (H4) diterima. Hasil penelitian ini sejalan dengan penelitian yang dilakukan oleh Dwirandra (2014) yang memperoleh hasil bahwa Pertumbuhan ekonomi berpengaruh signifikan serta mampu memoderasi pengaruh PAD terhadap belanja modal.

Hasil penelitian ini berbeda dengan penelitian yang dilakukan oleh Rian Yudhi Setiawan (2018) dimana memperoleh hasil bahwa pertumbuhan ekonomi tidak bepengaruh dalam memoderasi pendapatan asli daerah(PAD) terhadap belanja modal. Berdasarkan hasil penelitian ini yang menyatakan bahwa pertumbuhan ekonomi memoderasi (memperkuat)pengaruh PAD tehadap belanja modal. Atinya, semakin tinggi petumbuhan ekonomi maka pengaruh PAD terhadap belanja modal akan meningkat. Untuk meningkatkan pertumbuhan ekonomi pemerintah harus meningkatkan pengalokasin belanja daerahnya ke belanja modal dan menggunakan pendapatan asli daerahnya ke belanja modal. 


\section{Pertumbuhan Ekonomi Memoderasi Pengaruh Kekayaan Daerah Terhadap Belanja Modal}

Hipotesis kelima dalam penelitian ini adalah pertumbuhan Ekonomi memoderasi pengaruh kekayaan daerah terhadap belanja modal. Dimana pertumbuhan ekonomi yang tinggi akan meningkatkan pengaruh kekayaan daerah terhadap belanja modal. Tujuan dalam pembangunan adalah supaya perekonomian didaerah meningkat, dengan meningkatnya pertumbuhan ekonomi akan membuat sumber daya atau asset yang diperoleh akan meningkat, dan ini berarti bahwa pembiayaan anggaran banyak dialokasikan pada belanja modal.

Penelitian ini memperoleh hasil bahwa pertumbuhan ekonomi tidak memoderasi (memperlemah) pengaruh kekayaan daerah terhadap belanja modal (H5) ditolak. Artinya, pertumbuhan ekonomi yang tinggi akan membuat pengaruh kekayaan daerah terhadap belanja modal menurun. Pada saat petumbuhan ekonomi suatu daerah meningkat ini menggambarkan bahwa fasilitas dan pelayanan disuatu daerah tersebut sudah baik, maka dari itu pemeritah daerah akan mengurangi pengalokasian belanja modalnya dan mengalokasikan ke belanja lainnya seperti belanja pegawai dan belanja barang dan jasa.

\section{Pertumbuhan Ekonomi Memoderasi Pengaruh SILPA Terhadap Belanja Modal}

Hipotesis keenam dalam penelitian ini adalah Pertumbuhan ekonomi memoderasi Sisa Lebih Pembiyaan Anggaran (SILPA) terhadap belanja modal. Petumbuhan ekonomi yang meningkat berpengaruh langsung pada besarnya Sisa Lebih Pembiyaan Anggaran (SILPA) sehingga pemerintah dapat mengotimalkan penggunaan anggaran.

Dalam penelitian ini memperoleh hasil bahwa pertumbuhan ekonomi dapat memoderasi (memperkuat) pengaruh Sisa Lebih Pembiayaan Anggaran (SILPA) terhadap Belanja Modal. Hal ini berarti bahwa hipotesis keenam (H6) diterima. Penelitian ini sejalan dengan penelitian yang dilakukan oleh oleh Afrizal Surya Saputra (2020) yang memperoleh hasil bahwa pertumbuhan ekonomi memoderasi pengaruh SILPA terhadap belanja modal. Hasil penelitian ini berbeda dengan penelitian yang dilakukan oleh Supadmi (2014),dan penelitian yang dilakukan oleh F.Fahmi yang memperoleh hasil bahwa pertumbuhan ekonomi tidak memoderasi (memperlemah) pengaruh SILPA terhadap belanja modal.

Dalam penelitian ini yang memperoleh hasil bahwa prtumbuhan ekonomi memoderasi pengaruh Sisa Lebih Pembiyaan Anggaran (SILPA) terhadap belanja modal. Artinya adalah dengan meningkatnya pertumbuhan ekonomi akan membuat pengaruh Sisa Lebih Pembiyaan Aggaran (SILPA) terhadap Belanja Modal meningkat. Pada saat pertumbuhan ekonomi suatu daerah meningkat maka dapat diartikan bahwa perekonomian suatu daeah tersesbut membaik.

Peningkatan petumbuhan ekonomi ini berarti bahwa penerimaan atau pendapatan daerah lebih besar dibandingkan pengeluran daerah, dan ini menjelaskan bahwa jika pendapatan lebih besar dari pengeluaran maka SILPA tahun berjalan meningkat. Ketika suatu daerah mengalami peningkatan pertumbuhan ekonomi, maka pemerintah daerah akan mengurangi pembiyaan anggaran untuk belanja modal dan akan di alokasikan ke belanja lain seperti belanja pegawai, barang dan jasa dan lain-lain.

\section{SIMPULAN DAN SARAN \\ Simpulan}

Berdasarkan hasil penelitan dan pengujian hipotesis yang telah dilakukan peneliti, maka dapat ditarik kesimpulan penelitian ini sebagai berikut :

1. Pendapatan Asli Daerah (PAD) tidak berpengaruh signifikan terhadap belanja modal pada provinsi se-Indonesia tahun 2015-2019.

2. Kekayaan daerah berpengaruh signifikan terhadap belanja modal pada provinsi seIndonesia tahun 2015-2019. 
3. Sisa Lebih Pembiayaan Anggaran berpengaruh signifikan terhadap belanja modal pada provinsi se-Indonesia tahun 2015-2019.

4. Pertumbuhan ekonomi memoderasi (memperkuat) pengaruh Pendapatan Asli Daerah (PAD) terhadap belanja modal pada provinsi se-Indonesia tahun 2015-2019.

5. Pertumbuhan ekonomi tidak memoderasi (memperlemah) pengaruh kekayaan daerah terhadap belanja modal pada provinsi se-Indonesia tahun 2015-2019.

6. Pertumbuhan ekonomi memoderasi (memperkuat) pengaruh Sisa Lebih Pembiayaan Anggaran (SILPA) terhadap belanja modal pada Provinsi se-Indonesia tahun 2015-2019.

\section{KETERBATASAN}

Keterbatasan dalam penelitian ini adalah :

1. Penelitian ini hanya menggunakan tiga variabel independen yaitu Pendapatan Asli Daerah (PAD), kekayaan daerah, dan Sisa Lebih Pembiayaan Anggaran (SILPA) maka memberi peluang bagi peneliti selanjutnya untuk menggunakan variabel lain yang mempengaruhi belanja modal.

2. Rentang waktu data yang digunakan peneliti hanya 5 tahun periode yaitu tahun 2015-2019.

3. Penelitian ini menganalisis data hanya menggunakan uji moderated Regression Analysis (MRA) untuk menguji variabel independen dan interaksi variabel moderasi dengan variabel independen.

\section{SARAN}

Berdasarkan kesimpulan dan keterbatasan peneliti menyarankan :

1. Peneliti selanjutnya agar dapat menambahkan vaiabel lain yang mempengaruhi belanja modal.

2. Pemerintah provinsi diharapkan dapat memperhatikan alokasi anggaran yang khususnya bersumber dari Pendapatan Asli Daerah (PAD), supaya dapat mengupayakan alokasinya banyak ke belanja modal.

3. Bagi peneliti selanjutnya suapaya dapat menggunakan data tebaru serta menggunakan metode analisis yang lain untuk menguji hipotesisnya.

\section{DAFTAR PUSTAKA}

Adi, D. H. (2007). Hubungan Antara Dana Alokasi Umum, Belanja Modal,Pendapatan Asli Daerah dan Pendapatan Per Kapita.

Apa itu Pertumbuhan Ekonomi Dan Teori Pendukungnya. (t.thn.). Diambil kembali dari https://blogruangguru.com.

Dwirandra, P. N. (2014). Pengaruh Pendaptan Asli Daerah Pada Belanja Modal dengan Pertumbuhan Ekonomi Sebagai Variabel Pemoderasi. E-Jurnal Akuntansi Universitas Udayana 7.1 (2014) .

Elni. (2019). Pengaruh Pendapatan Asli Daerah dan Dana Alokasi Khusus Terhadap Belanja Modal . E-jurnal Katalogis Vol 4 No 2 , 1-11.

frelistiyani, H. D. (2004). Pengaruh Dana Alokasi Umum Terhadap Pendapatan Asli Daerah Dengan Belanja Modal Sebagai Intervening.

Frelistiyani, W. (2010). Pengaruh Dana Alokasi Umum Terhadap Pendapatan Asli Daerah Dengan Belanja Modal Sebagai Variabel Intervening.

Ghozali, I. (2009). Aplikasi Analisis Multivariate Dengan Program SPSS. Semarang: Universitas Diponegoro.

Halim. (2011). Akuntansi Keuangan Daerah. Jakarta: Selemba Empat. 
Jaeni, G. A. (2016). Pertumbuhan Ekonomi Sebagai Variabel Pemoderasi Pendapatan Asli Daerah dan Dana Alokasi Khusus Terhadap Belanja Modal. ISBN .

Mardiasmo. (2002). Otonomi Dan Manajemen Keuangan Daerah. Yogyakarta: Andi.

Misra, U. D. (2019). Pengaruh Kekyaan Daerah Dan Belanja Modal Terhadap Kinerja Penyelenggaraan. E-jurnal Akuntansi,7792, 2019.

Nugroho, F. (2012). Pengaruh Belanja Modal Terhadap Pertumbuhan Kinerja Keuangan Daerah Sebagai Variabel Intervening.

Oktaviani, E. A. (2015). Pengaruh Pendapatan Asli Daerah dan Dana Alokasi Umum Terhadap Belanja Modal Dengan Pertumbuhan Ekonomi Sebagai Pemoderasi. Dinamika Akuntansi, Keuangan dan Perbankan Vol 4 No 2 , 190-205.

Pamudji, N. S. (2011). Pengaruh Pertumbuhan Ekonomi, Pendapatan Asli Daerah dan Dana Alokasi Umum Terhadap Penaglokasian Anggaran Belanja Modal.

Pengertian Belanja Modal, Jenis Dan kriteria Belanja Modal. (t.thn.). Diambil kembali dari http://www.e-akuntansi/ Pengertian Belanja Modal , Jenis dan Kriteria Belanja Modal.

Permendagri No. 59 Tahun 2007 Pasal 53 Ayat (1). (t.thn.).

Permendagri Nomor 13. (2006).

Permendagri Nomor 13. (2013). Tentang Pedoman Pengelolaan Keuangan Daerah .

Permendagri Nomor 33. (2019).

PP 71. (2010). lampiran I.02 Penyajian Laporan Keuangan .

PP No 24. (2005). Tentang Standar Akuntansi Pemerintah .

PP Nomor 58 . (2005). Tentang Pengeloaan keuangan Daerah .

Prakoso, K. B. (2004). Analisis Pengaruh Dana Alokasi Umum (DAU) Dan Pendptan Asli Daerah (PAD) Terhadap Prediksi Belanja Daerah. JAAI Volume 8 no 2.

Prasetya, I. (2017). Pengaruh Pendapatan Asli Daerah, Dana Alokasi Umum, Dana Alokasi Khusus, Dana Bagi Hasil Dan Belanja Pegawai Terhadap Pengelokasian Anggaran Belanja. Jurnal Akuntansi 5 (2), $2017,1$.

Priambudi, W. (2017). Pengaruh Pendapatan Asli Daerah dan Dana Alokasi Umum Terhadap Belanja Modal pada Kabupaten dan Kota di Pulau Jawa Tahun 2013. Vol.06 No 01 .

Riviando, Adel; Agustin, Henri; Halmawati. (2019). Pengaruh Pendapatan Asli Daerah, Dana Alokasi Umum, dan Dana Alokasi Khusus terhadap Indek Pembangunan Manusia dengan Belanja Modal Sebagai Variabel Intervening. Jurnal Eksplorasi Akuntansi. 1(1). Seri A. 1-17

Regina Usman, F. M. (2019). Penagruh Kekayaan Daerah Dan Belanja Modal Terhadap Kinerja Penyelengaraan Pemerintah Pengujian Legislativ Power Sebagai Variabel Pemoderasi. E-JA Vol 29 No 2 .

Rendy Armando Kakasih, G. M. (2018). Pengaruh pendapatan Asli Daerah dan Dana Alokasi Umum Terhadap Belanja Modal Pada Kabupaten dan Kota di Provinsi Sulawesi Utara Periode 2009-2016. Jurnal Berkala Ilmiah Efisiensi Vol.18 No 02 .

Supadmi, N. P. (2014). Pengaruh PAD, DAU, Dan SILPA Belanja modal Dengan Pertumbuhan Ekonomi Sebagai Pemoderasi. E-jurnal Akuntansi Universitas Udyana 7.2 (2014) .

Undang-Undang No 32. (2004). Tentang Perimbangan Keuangan Antara Pemerintah Pusat Dan Pemerintah Daerah .

Undang-Undang No.32 Tahun 2004 Tentang Pemerintah Daerah. (t.thn.).

Windra, A. G. (2013). Pengaruh PAD, DAU,DAK, Dan DBH Terhadap Pengalokasian Belanja Modal. Jurnal Akuntansi 2 (1) 2013.

Yana, W. (2018). Pengaruh PAD, DAU, DBH, Dan DOK Terhadap Belanja Modal dengan SILPA sebagai Variabel Pemoderasi . 